\title{
PENINGKATAN KEMAMPUAN MENYUSUN KALIMAT BAHASA ARAB MELALUI PEMBELAJARAN BERBASIS KERJA SAMA (PBK)
}

\author{
Yumna Rasyid dan Syamsi Setiadi \\ Fakultas Bahasa dan Seni, Universitas Negeri Jakarta, Jln. Pemuda Jakarta Timur \\ e-mail: yumzai.rasyid@gmail.com
}

\begin{abstract}
This research aims to improved recitation achievement in writing Arabic language by language learning based on working together. This research conducted in 2 cycles, each cycles have for components are: Action, obsevation, and reflection. The results showed student achievement in sentence writing improved every cycles. In conclusion that application learning strategy with PBK can improved learning quality for Nahu 2 related to making simpel sentences and appropriate as the rules of Arab fusha. As suggested for $P B K$ can be applicated not only in Nahu 2 learning but also in the other elements arabic language
\end{abstract}

Keywords: Arabic language, language learning based on working together

\begin{abstract}
Abstak
Penelitian tindakan kelas ini bertujuan meningkatkan hasil belajar menulis kalimat dalam bahasa Arab melalui Pembelajaran Bahasa berbasis Kerja sama (PBK). Penelitian dilaksanakan dalam dua siklus, setiap siklus berisi empat komponen, yaitu: perencanaan; aksi/tindakan; observasi; dan refleksi. Hasil penelitian menunjukkan hasil belajar siswa dalam menulis kalimat meningkat dari setiap sik-lusnya. Dengan demikian dapat disimpulkan bahwa penerapan strategi mengajar dengan PBK dapat meningkatkan kualitas pembelajaran Nahu 2 yang menyangkut materi penyusunan kalimat sederhana sesuai kaidah tatabahasa Arab fusha. Disarankan agar PBK dapat diterapkan bukan hanya dalam pembelajaran Nahu 2 tapi juga pada pembelajaran unsur-unsur bahasa Arab yang lain.
\end{abstract}

Kata Kunci: kalimat bahasa arab, pembelajaran berbasis kerjasama

\section{PENDAHULUAN}

Latar belakang penelitian ini dapat dilihat dari dua sisi, yaitu permasalahan dari segi bahasa, dan dari segi pembelajar. Dari segi bahasa, bahwa bahasa Arab memiliki aturan-aturan yang berbeda dari aturanaturan bahasa Indonesia karena itu akan menimbulkan permasalahan bagi pembelajar. Bahasa Arab mengenal beberapa kategori kata benda, seperti: (a) kategori tunggal (mufrad), dual (mustanna) dan jamak (jama'); (b) kategori feminin (muannast) dan maskulin (muzdakkar); (c) kategori tentu (ma'rifah) dan tak tentu (nakirah).

Kata kerja juga memiliki beberapa kategori, kata kerja masa lampau ( $f i^{\prime} l$ madhi), kata kerja masa sekarang dan masa yang akan datang ( $f i^{\prime} l$ mudhari'), dan kata kerja perintah ( $f i^{\prime} l \mathrm{amr}$ ). Bentukan kata kerja ini sangat dipengaruhi oleh subjeknya atau oleh kata ganti (dhamir), baik kata ganti orang pertama (mutakallim), orang kedua (mukhathab), dan orang ketiga (ghaib). Konsekuensi dari karakteristik bentukan kata kerja seperti itu adalah kata fi'l madhi memiliki 14 bentukan, fi'l mudhari' 14 bentukan, dan fi'l amr 6 bentukan. Kategori kata benda dan kata kerja ini sangat mempengaruhi tingkat kemampuan mahasiswa pemula dalam menyusun kalimat secara praktis dan otomatis.

Permasalahan dilihat dari sudut pembelajar, pertama bahwa ada kecenderungan sebagian pembelajar kurang memiliki waktu untuk belajar dengan sungguh-sungguh disebabkan kesibukan lain di luar kampus, kedua bahwa sebagian besar latar belakang pengalaman belajar bahasa Arab mahasiswa masih 
sangat minim. Ketiga bahwa cara belajar yang masih individual, kurang adanya diskusi di antara mereka dan tidak terlihat kerja sama dalam menyelesaikan berbagai permasalahan dalam pelajaran bahasa Arab. Situasi seperti ini tidak medukung keberhasilan belajar mahasiswa, oleh sebab itu perlu suatu cara dan stra-tegi dalam meningkatkan motivasi terutama dalam pelajaran menyusun berbagai bentuk kalimat dalam pelajaran berbicara dan menulis bahasa Arab.

Kerja sama dalam meningkatkan kemampuan menyusun kalimat bahasa Arab dalam latihan berbicara dan menulis dapat memberikan solusi pemecahan masalah belajar bahasa asing. Salah satu strategi yang mungkin dapat membantu meningkatkan keterampilan menyusun kalimat sederhana untuk menulis dan berbicara tersebut pendekatan pengajaran bahasa berbasis kerja sama (PBK) merupakan terjemahan dari bahasa Inggris Cooperative Language Learning (CLL). Penerapan PBK ini diharapkan dapat meningkatkan kerja sama yang baik antar individu dalam dalam rangka meningkatkan kemampuan mahasiswa menyusun kalimat sederhana bahasa Arab selanjutnya sebagai landasan menyusun karangan sederhana, selanjutnya semangat belajar ma-hasiswa dalam mempelajari bahasa Arab juga meningkat.

Berdasarkan latar belakang masalah di atas, dirumuskan masalah penelitian sebagai berikut:

1. Apakah dengan menerapkan pendekatan Pembelajaran Bahasa berbasis Kerja sama (PBK), dapat meningkatkan kemampuan mahasiswa dalam menyusun berbagai macam bentuk kalimat dalam karangan bahasa Arab sederhana?

2. Apakah penerapan PBK dapat meningkatkan kerja sama dan semangat belajar maha-siswa?

3. Apakah penerapan PBK dapat menciptakan suasana belajar bahasa Arab yang kondusif?

\section{A. Pembelajaran Berbasis Kerja sama}

Pembelajaran Bahasa berbasis Kerja sama/Kooperatif (PBK) merupakan bagian da-ri pendekatan instruksional yang lebih umum yang dikenal juga sebagai Pembelajaran Kolaboratif (PK). Pembelajaran berbasis Kerja sama adalah sebuah pendekatan peng-ajaran yang memanfaatkan kegiatan kooperatif secara maksimum dengan melibatkan pasanganpasangan dan kelompok kecil pembelajar di kelas.

Pembelajaran Berbasis Kerjasama/ Kooperatif adalah kegiatan belajar kelompok yang diatur sedemikian rupa hingga pembelajaran bergantung pada pertukaran informasi yang terstruktur secara sosial di antara pembelajar dalam kelompok. Dalam kelompok tersebut setiap pembelajar bertanggungjawab atas pembelajaran mereka masing-masing dan termotivasi untuk memperluas pe-ngetahuan lainnya. (Olsen dan Kagan 1992: 8)

$$
\text { Pembelajaran Kooperatif ini }
$$
mencoba melakukan hal-hal berikut ini:

1. meningkatkan prestasi seluruh siswa, termasuk mereka yang berbakat atau secara akademik mendapat banyak kendala;

2. membantu guru membangun hubungan positif di antara siswa;

3. memberi siswa pengalaman berharga yang mereka butuhkan berupa peningkatan hu-bungan sosial, psikologis, dan kognitif;

4. Mengganti struktur aturan yang kompetitif dari kebanyakan kelas dan sekolah dengan struktur aturan yang berkinerja tinggi yang berbasis kelompok.

Dalam pengajaran bahasa kedua, PBK mencakup berbagai cara untuk meningkatkan interaksi komunikatif di dalam kelas dan dianggap sebagai perluasan dari prinsip-prinsip Pengajaran Bahasa Komunikatif. Pengajaran ini dipandang sebagai pendekatan pengajaran yang berpusat pada siswa tetapi tetap mempertahankan manfaat-manfaat dari metode pembelajaran guru sebagai pusat.

Dari perspektif pengajaran bahasa ke-dua, McGroarty (1989) menyebutkan 
enam manfaat pembelajaran bahasa dengan PKB:

1. frekuensi dan berbagai praktik bahasa kedua dapat ditingkatkan melalui jenis-jenis interaksi yang berbeda;

2. kemungkinan untuk mengembangkan atau memanfaatkan bahasa dengan caracara yang mendukung perkembangan kognitif dan keterampilan berbahasa yang mening-kat;

3. kesempatan untuk mengintegrasikan bahasa dengan instruksi berbasis isi;

4. kesempatan untuk memasukkan berbagai materi kurikulum yang jauh lebih besar untuk menstimulasi pembelajaran bahasa sebagaimana halnya pembelajaran konsep;

5. kebebasan bagi guru untuk menguasai keterampilan profesional yang baru, khususnya bagi mereka yang menekankan komunikasi;

6. kesempatan bagi siswa untuk bersikap seba-gai nara sumber bagi satu dengan lainnya, sehingga dapat diasumsikan bahwa siswa dapat berperan lebih aktif dalam pembela-jaran mereka.

Keberhasilan PBK sangat tergantung pada ciri-ciri dan organisasi kerja kelompok. Hal ini mempersyaratkan program pembelajaran terstruktur yang benar-benar dirancang sehingga siswa dapat berinteraksi satu dengan lainnya dan termotivasi untuk meningkatkan pembelajaran mereka masingmasing. Di bawah ini, Olsen dan Kagan (1992) mengusulkan unsur-unsur utama keberhasilan PBK, yaitu interdependensi positif, pembentukan kelompok, tanggung jawab individu, keteram-pilan sosial, dan penstrukturan dan struktur.

Interdependensi positif terjadi jika anggota kelompok merasa bahwa sesuatu yang bisa menolong satu anggota berarti menolong semua anggota dan sesuatu yang menyakiti satu anggota berarti menyakiti semuanya.

Tanggung jawab individu melibatkan kinerja kelompok dan individu, misalnya, de-ngan menugaskan setiap siswa untuk bertang-gung jawab atas bagiannya dalam projek tim atau dengan memanggil siswa secara acak untuk berbagi dengan seluruh kelas, anggota kelompok, atau kelompok lainnya.

Keterampilan sosial menentukan cara siswa beinteraksi satu dan lainnya sebagai ang-gota tim.

Penstrukturan dan struktur mengacu cara-cara mengorganisir interaksi siswa dan cara-cara siswa berinteraksi.

Olsen dan Kagan (1992: 88) menjelaskan kegiatan pembelajaran bahasa berbasis kerja sama yang terdiri dari tiga tahap Interview:

1. siswa berpasangan, seorang sebagai pewa-wancara dan pasangannya sebagai yang diwawancara.

2. siswa berganti peran

3. masing-masing menjelaskan kepada anggota kelompoknya apa yang telah mereka pelajari selama dua kegiatan interview tersebut.

Kegiatan PBK ini dapat dilakukan dengan berbagai cara, antara lain:

1. Round table (meja bundar), untuk setiap tim disediakan secarik kertas dan sebuah bal-poin.

a) salah seorang siswa memberikan umpan

b) memberikan kertas dan pulpen kepada siswa di sebelah kirinya

c) tiap siswa melakukan hal sama secara bergantian

Apabila dilakukan secara lisan, struktur seperti ini disebut Round Robin.

\section{Think pair share}

a) guru memberikan satu pertanyaan (biasanya satu pertanyaan berdasarkan kese-pakatan)

b) siswa memikirkan jawabannya

c) siswa mendiskusikan jawaban tersebut dengan pasangannya

d) siswa menjelaskan jawaban pasangannya kepada seluruh anggota kelas 


\section{Solve Pair Share}

a) guru memberikan suatu masalah (masalah yang mungkin bisa dipecahkan de-ngan berbagai cara).

b) siswa berusaha mencari pemecahannya secara individual

c) siswa menjelaskan bagaimana cara mereka memecahkan masalah dalam interview atau Round Robin.

\section{Numbered Heads}

a) Siswa berhitung dalam satu tim

b) Guru mengajukan satu pertanyaan

c) Siswa berkumpul untuk mencari jawabannya dan memastikan setiap anggota kelompok mampu menjelaskan jawaban tersebut

d) Guru memanggil satu nomor dan siswa dan nomor tersebut mengangkat tangan seperti dalam kelas tradisional.

Peran utama siswa sebagai anggota kelompok adalah harus dapat bekerja sama dengan anggota lainnya untuk menyelesaikan tu-gas. Siswa harus belajar keterampilan kerja kelompok. Siswa juga yang mengarahkan pembelajarannya sendiri. Mereka diajar merencanakan, memonitor dan mengevaluasi proses belajarnya sendiri. Hal itu merupakan kete-rampilan belajar seumur hidup. Jadi, pembe-lajaran merupakan sesuatu yang membutuh-kan keterlibatan siswa secara aktif dan langsung. Kelompok berpasangan merupakan ciri khas dari pembelajaran bahasa berbasis kerja sama.

Adapun peran guru dalam PBK berbeda dari peran guru dalam pengajaran tradisional (guru sebagai pusat). Guru harus menciptakan lingkungan pembelajaran yang terorganisir dan terstruktur dengan baik di ruang kelas, menentukan tujuan, merencanakan dan menyusun tugas-tugas, membentuk tata ruang kelas, menentukan tugas dan peran siswa, serta menyeleksi materi dan waktu. Peran penting guru adalah fasilitator pembelajaran. Dalam perannya sebagai fasilitator, guru harus me-ngelilingi kelas membantu siswa dan kelom-pok jika diperlukan.
Selama pelajaran guru berinteraksi, mengajar, mefokuskan kembali, menanyakan, mengklarifikasi, mendukung, memperluas, merayakan, menekankan, bergantung pada permasalahan yang berkembang. Fasilitator memberikan umpan balik, mengarahkan ke-lompok dengan pertanyaan, mendorong ke-lompok menyelasaikan problem mereka sen-diri, memperluas kegiatan, mendorong untuk berpikir, mengelola konflik, mengamati siswa, dan mensuplai sumber-sumber daya.

Guru berbicara lebih sedikit dari kelas tradisional. Mereka menyediakan banyak pertanyaan yang menantang siswa untuk berpikir, mereka mempersiapkan tugas-tugas yang akan dilakukan siswa, mereka membantu siswa dengan tugas-tugas pembelajaran, serta memberi sedikit perintah, tidak lebih sebagai pengen-dalian disiplin. Guru bisa saja mempunyai tugas menyusun pelajaran sehingga siswa da-pat mempekerjakan diri mereka sendiri secara bersama-sama.

Selain peran siswa dan guru, materi juga memainkan peran penting dalam pencip-taan kesempatan bagi siswa untuk bekerja sama. Materi-materi yang sama dapat digunakan sebagaimana digunakan dalam jenis-jenis pelajaran lainnya namun variasi diperlukan umtuk mengetahui bagaimana materi tersebut digunakan. Misalnya, jika siswa bekerja dalam kelompok, masing-masing memiliki seperangkat materi (atau kelompok bisa memiliki sejumlah perangkat materi), atau masing-masing anggota kelompok mungkin perlu menggandakan teks yang akan dibaca dan dirujuk.

\section{B. Kalimat Sederhana dalam Bahasa Arab}

Kalimat sederhana (klausa) dalam ba-hasa Arab ada dua macam, klausa ismiyah (jumlah ismiyah) dan klausa fi'liyah (jumlah fi'liyah). Masing-masing memiliki ketentuan tersendiri. Klausa ismiyah terdiri dari dua unsur, subjek dan predikat yang disebut mubtada dan khabar. Keduanya harus sesuai (mu-thabaqah) dari segi 
mufrad, mustanna, jamak, muannas dan mudzakkar. Klausa fi'liyah ter-diri dari kata kerja ( $\left.f i^{\prime} l\right)$, subjek (fa'i)l dan objek (maf'ul). Kata kerja terbagi kepada transitif dan intransitif, aktif dan pasif, kata da-sar atau berimbuhan dan lain-lain.

Kalimat sederhana ini dapat dilengkapi dengan kata-kata lain, seperti kata depan (harf jar), kata keterangan tempat dan waktu (zharf makan wa zaman), kata ganti (dhamir), kata penununjuk (ism isyarah), kata penghubung (ism maushul), dan kata tugas lainnya.

Klausa sederhana ini juga didukung oleh frase yang terdiri dari na'at man'ut, idha-fah (kata majemuk), jar majrur dan lain-lain. Susunan kalimat ini sangat dipengaruhi oleh subjek, baik dari segi tunggal (mufrad), dual (mutsanna), jamak (jam'), feminin (muan-nast), dan maskulin (mudzakkar).

Kalimat sederhana ini diajarkan pada mata kuliah Nahu (Sintaksis Arab) I. Di dalamnya sudah tercakup konsep-konsep dasar yang harus dikuasai mahasiswa dalam menyu-sun kalimat sederhana. Kalimat sederhana ini dikembangkan menjadi kalimat yang lebih kompleks dengan menambah bermacam-macam bentuk keterangan atau dengan mengu-bah susunan kalimat menjadi berbagai variasi. Pengembangan kalimat sederhana ini diberikan pada mata kuliah Nahu II.

Penelitian tidak hanya melihat penguasaan mahasiswa dalam menyusun kalimat sederhana saja, tapi kalimat sederhana yang sudah dikembangkan menjadi kalimat yang lebih kompleks. Materi yang dipakai dalam penelitian tindakan ini adalah cakupan materi Nahu I yang dikembangkan dengan materi Nahu II. Untuk melihat hasil penguasaan mahasiswa dalam menyusun kalimat ini dilihat dari dua cara, yaitu dengan penugasan membuat kalimat lepas, mengubah dari satu bentuk struktur ke bentuk lain, mengubah subjek, menambah berbagai macam keterangan, atau de-ngan penugasan membuat karangan pendek. Dalam karangan ini mahasiswa harus meng- gunakan bentuk-bentuk kalimat yang sedang dipelajari.

Penelitian ini bertujuan:

1. Meningkatkan kemampuan mahasiswa me-nyusun kalimat dalam bahasa Arab dengan baik dan benar secara tulisan. Baik dari segi pilihan katanya dan benar dari segi aturannya.

2. Berusaha meningkatkan kerja sama dan semangat belajar mahasiswa dalam mempelajari berbagai macam-macam kalimat bahasa Arab.

3. Menciptakan situasi belajar bahasa Arab yang lebih kondusif dengan penerapan pen-dekatan PBK

\section{METODOLOGI PENELITIAN}

Penelitian ini merupakan penelitian tindakan kelas (classroom-based action research). Penelitian ini menggunakan model Kemmis \& Taggart, yaitu dengan melaksana-kan pengkajian berdaur yang terdiri dari 4 ta-hap, yaitu tahap perencanaan, tahap tindakan/aksi, tahap observasi/pengamatan interpretasi, dan tahap refleksi.

Tahap perencanaan dilakukan dengan melakukan tes awal secara tertulis. Tahap tindakan siklus I dilakukan pada pertemuan kedua sampai pertemuan kedelapan. Pertemuan kesembilan dilakukan tes tertulis akhir siklus I. Tes ini bertujuan untuk melihat kemajuan mahasiswa dalam menerapkan konsep-konsep penyusunan kalimat. Di samping itu mahasis-wa ditugaskan membuat karangan sederhana dengan topik yang telah ditetapkan. Mereka diharapkan menerapkan bentuk-bentuk kalimat yang diajarkan dalam karangan mereka. Tes dan tugas karangan ini dijadikan sebagai bahan refleksi bagi dosen untuk menggariskan apakah (PBK) ini dapat membantu mahasiswa lebih mahir dalam menyusun kalimat-kalimat sederhana yang lebih kompleks.

Siklus II dilkukan pada pertemuan kesepuluh sampai pertemuan ke lima belas. Tes akhir siklus II dilakukan pada pertemuan keenam belas. Pada setiap pertemuan 
dilakukan pengamatan. Dilihat bagaimana sikap, perhatian, dan semangat masingmasing individu mahasiswa dalam setiap kelompok, begitu juga kerja sama mahasiswa dalam kelompok dalam menyelesaikan setiap tugas, atau dalam menyimpulkan konsep-konsep materi yang sedang dipelajari. Di akhir setiap pertemuan diadakan dialog langsung antara dosen dengan mahasiswa.

Subjek penelitian adalah mahasiswa yang mengikuti mata kuliah Nahu II sebanyak 23 orang. Pada mata kuliah ini mahasiswa akan memperoleh materi yang berhubungan dengan bermacam-macam pengembangan kalimat sederhana dalam bahasa Arab.

Penelitian ini dilaksanakan di Jurusan Bahasa dan Sastra Arab, Fakultas Bahasa dan Seni, Universitas Negeri Jakarta. Direncanak-an pelaksanaannya selama lima bulan.

\section{HASIL DAN PEMBAHASAN}

\section{A. Pelaksanaan Siklus I}

Seperti sudah dijelaskan sebelumnya, setiap siklus melalui empat tahap, perencanaan, tindakan, pengamatan, dan refleksi. Pertemuan-pertemuan pada siklus I sebanyak sembilan kali pertemuan yang terdiri dari satu kali tes awal, tujuh kali tindakan, dan satu kali tes akhir siklus I. Di bawah ini akan dijelaskan satu persatu.

\section{1) Perencanaan}

Perancanaan ini berdasarkan kepada identifikasi masalah yang sudah diuraikan di atas. Dosen menjelaskan pokok-pokok bahasan yang akan dipelajari pada Nahu II ini yang sesuai dengan silabus yang telah ditetapkan. Termasuk di dalamnya tujuan, bentuk kegiat-an, serta tugas-tugas yang harus dilakukan oleh mahasiswa. Penyajian materi dan pemberian penguatan yang terfokus pada kesalahan-kesalahan yang sering dilakukan mahasiswa dalam menyusun kalimat-kalimat bahasa Arab secara tertulis. Materi-materi tersebut meliputi pengembangan klausa ismiyah dan klausa fi'li-yah, yang merupakan lanjutan dari materi Na-hu I.

\section{Pertemuan ke-1:}

Tes awal, untuk mengidentifikasi masalah yang dialami mahasiswa.

\section{Pertemuan ke-2:}

Penyajian materi I: (أنواع الخبر), yaitu macam-macam predikat. Pada Nahu I mahasiswa sudah mempelajari klausa ismiyah yang terdiri dari mubtada (suyek) dan khabar (pre-dikat).

\section{Pertemuan ke-3:}

Penyajian materi 2: تقدم الخبر على) , المبندأ). yaitu variasi kalimat dengan mendahulukan predikat dari subjek.

\section{Pertemuan ke-4:}

Penyajian materi 3: 3: النواسخ: وأخو اتها) yaitu variasi klausa ismiyah dengan menggunakan Kana dan sejenisnya.

\section{Pertemuan ke-5:}

Penyajian materi 4: النواسخ: وأخواتها), yaitu variasi kalausa ismiyah dengan menggunakan Inna dan sejenisnya.

\section{Pertemuan ke-6:}

Penyajian materi أنواع الصفة:5aitu macam-macam kelompok kata yang mengandung sifat.

\section{Pertemuan ke-7:}

Penyajian materi 6: (الأسماء الخمسة), ya-itu kasus kata tertentu yang mempunyai ketentuan khusus tergantung kedudukannya dalam kalimat.

\section{Pertemuan ke-8:}

Penyajian materi 7: (التمييز), yaitu menyangkut penggunaan takaran, ukuran, timbangan, dan bilangan.

\section{Pertemuan ke-9:}

Tes (الاختبار الأول) , yaitu tes akhir siklus I untuk mengetahui sejauh mana 
mahasiswa menguasai materi dengan penerapan PBK. Setelah tes, diadakan refleksi dan evaluasi untuk menilai sejauh mana efektifitas penerapan PBK. Apabila tujuan sudah tercapai, kegiatan berhenti sampai di sini, tapi kalau masih belum memuaskan, dengan arti kata tujuan belum ter-capai, maka kegiatan di-lanjutkan ke siklus ke-dua.

\section{2) Tindakan}

Tindakan pada siklus I terdiri dari satu kali tes awal, tujuh kali penyajian materi, dan satu kali tes akhir siklus I. Penyajian materi dimulai dari pertemuan ke dua sampai pertemuan ke delapan. Seluruhnya terdapat sembilan kali pertemuan. Di bawah ini akan dijelaskan uraian penyajian materi dari pertemuan ke dua sampai kedelapan.

\section{Tindakan pertemuan ke-1: Tes awal}

Tes ini dilaksanakan untuk mengiden-tifikasi kesalahan-kesalahan mahasiswa dalam menyusun kalimat sederhana dalam bahasa Arab. Hasil tes ini tidak berbentuk angka, tapi berbentuk prosentase kesalahan.

\section{Tindakan pertemuan 2: Penyajian materi 1}

Mahasiswa dibagi menjadi 5 kelompok. Kelompok 1 dan 2 terdiri dari 4 orang, ke-lompok 3, 4 dan 5 terdiri dari 5 orang. Dosen pertama-tama menjelaskan materimateri yang akan dipelajari dari awal sampai tengah semester, kegiatan-kegiatan yang akan dilaksanakan, serta tugas-tugas yang harus diselesaikan sampai tengah semester.

Setelah itu langsung masuk materi I mengenai macam-macam predikat pada klau-sa/kalimat ismiyah. Dosen menjelaskan kaidah-kaidah dasar dengan memberi contoh dalam teks pendek. Setelah itu diberikan teks lain. Mahasiswa diarahkan untuk mendiskusikan teks tersebut untuk mendapatkan kalimat-kalimat lain yang mengandung berbagai macam predikat. Mereka harus merumuskan kai-dah-kaidah yang berhubungan dengan materi. Setelah itu mereka diberi latihan-latihan menyusun kalimat yang diselesaikan secara kelompok. Setiap kelompok diberi tugas yang berbeda. Setelah itu setiap kelompok disuruh menyajikan apa yang mereka kerjakan, agar ditanggapi oleh kelompok lain.

Setelah itu dosen mengomentari dan membetulkan kesalahan yang ada. Terakhir dosen memberi tugas kelompok yang harus diselesaikan sampai pertemuan berikut. Cara ini dilakukan dalam setiap pertemuan. Pelaksanaan pertemuan materi 1 ini sudah sesuai dengan rencana pelajaran (terlampir). Keberhasilan ini terlihat dari pengamatan kolaborator.

Tindakan pertemuan ke-3: Penyajian materi 2

Penyajian materi 2 adalah materi tentang berbagai bentuk variasi, yaitu predikat mendahului subjek dalam klausa/kalimat ismiyah. Sebelum masuk materi baru, dosen memberikan komentar terhadap tugas rumah yang dibuat kelompok dengan cara mendiskusikannyan dengan mahasiswa.

Setelah itu baru masuk materi baru dengan cara yang sama dengan penyajian materi 1. Diakhir pelajaran siswa diberi tugas individu dengan membuat karangan pendek dengan menggunakan bentuk-bentuk kalimat yang dibahas pada materi 1 dan 2 . Pelaksanaan pertemuan materi 2 ini sudah sesuai dengan rencana pelajaran.

Tindakan pertemuan ke-4: Penyajian materi 3

Penyajian materi 3 adalah materi yang berhubungan dengan pengembangan kalimat ismiyah dengan penggunaan Nawaasikh bagian satu, yaitu Kaana dan sejenisnya. Pelaksanaannya sama dengan kegiatan sebelumnya, dengan ketercapaian rencana pelajaran.

Tindakan pertemuan ke-5: Penyajian materi 4

Penyajian materi 4 adalah materi yang berhubungan dengan Nawaasikh 
bagian dua, yaitu Inna dan sejenisnya. Materi 3 dan 4 ini adalah pengembangan kalimat ismiyah dengan menggunakan kata bantu kaana dan sejenisnya, dan inna dan sejenisnya. Pelaksanaan penyajian materi 4 sesuai dengan rencana pelajaran yang sudah disusun.

Tindakan pertemuan ke-6: Penyajian materi 5

Penyajian materi 5 adalah materi yang berhubungan dengan macam-macam shifat atau na'at. Materi ini berhubungan dengan pembentukan kelompok kata yang terdiri dari kata dan sifatnya. Ada tiga macam bentuk shifat atau na'at. Struktur shifat msushuf atau na'at man'ut ini dapat digunakan dalam pengembangan kalimat ismiyah atau kallimat fi'liyah. Pelaksanaan penyajian materi 5 ini sesuai dengan rencana pelajaran yang sudah disusun.

Tindakan pertemuan ke-7: Penyajian materi 6

Penyajian materi 6 adalah materi yang berhubungan dengan Al Asmaa'ul Khamsah (isim yang lima). Lima kata ini memiliki kaidah tersendiri yang berbeda dari kata benda yang lain. Bentuknya akan berubah sesuai kedudukannya. Pelaksanaan penyajian materi 6 ini sesuai dengan rencana pelajaran yang sudah disusun (terlampir).

Tindakan pertemuan ke-8: Penyajian materi 7

Materi yang disajikan pada pertemua ke-8 berhubungan dengan pengembangan kalimat fi'liyah dengan penambahan keterangan pembeda (tamyiiz). Pembeda ini berhubungan dengan takaran, timbangan, ukuran, dan bilangan. Pelaksanaan penyajian materi ini sudah sesuai dengan rencana pelajaran yang sudan disusun (terlampir). Materi 7 adalah materi terakhir dari siklus I. Di akhir pertemuan 8 ini mahasiswa diberi 2 tugas rumah, satu tugas kelompok dan satu lagi tugas individu. Tugasnya sama, yaitu membuat karangan pendek dengan memilih salah satu topik yang telah ditentukan oleh dosen. Topiknya ada empat buah, yaitu:

$$
\begin{aligned}
& \text { 2- 1- شمر رمالي اليوميّة } \\
& \text { 3- العطلة في القرية }
\end{aligned}
$$

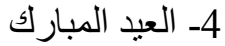

Dalam karangan ini mahasiswa harus menerapkan stsruktur kalimat yang sudah dipelajari. Di akhir karangan mahasiswa harus menjelaskan sruktur-struktur kalimat yang digunakan dalam karangan. Kedua tugas ini harus diserahkan pada pertemuan ke-9.

Tindakan pertemuan ke-9: Tes akhir siklus I

\section{3) Pengamatan}

\section{Pertemuan ke-2}

Pengamatan yang dilakukan selama penelitian ini adalah pengamatan terhadap kegiatan pembelajaran dengan penggunaan Pembelajaran bahasa Berbasis Kerja sama (PBK). Perkuliahan direncanakan berlangsung selama 100 menit. Untuk mengamati pelaksanaan jalannya setiap tindakan khusus-nya kegiatan pembelajaran pada setiap siklus digunakan lembar pengamatan. Pengamatan dilakukan oleh kolaborator.

Siklus pertama ini dimulai dari pertemuan kedua mata kuliah Nahu II, karena pertemuan pertama digunakan untuk tes awal untuk mengidentifikasi kesulitan dan kesiapan mahasiswa dalam mengikuti pelajaran Nahu II. Pelajaran dimulai dengan pendahuluan. Pertama dosen menjelaskan garis besar materi yang akan dipelajari dari awal semester sampai tengah semester.

Dosen menjelaskan tugas-tugas yang harus dilakukan setiap kelompok dan setiap individu. Dosen mengulang materi yang sudah dipelajari pada Nahu 1 khususnya tentang mubtada dan khabar /kalimat ismiyah secara ringkas. Mahasiswa dikelompokkan dalam lima kelompok. Dosen memberikan teks yang ada hubungannya dengan topik atau pokok bahasan materi 1. Topik dalam pertemuan ini adalah (أنو اع الخبر) 
Pada bagian inti, dosen mengelompokkan mahasiswa menjadi lima kelompok. Kemudian Dosen membacakan sebuah teks yang berhubungan dengang materi. Dosen menjelaskan kaidah-kaidah yang berhubungan dengan materi. Setiap kelompok diminta untuk mendiskusikan teks tersebut dengan mengidentifikasi bentukbentuk kalimat yang sesuai dengan topik. Setiap kelompok menyimpulkan hasil diskusi.

Wakil setiap kelompok maju bergantian menjelaskan hasil diskusi. Mahasiswa lain menanggapi hasil diskusi tersebut secara bergantian. Dosen menanggapi dan membetulkan kesimpulankesimpulan yang keliru. Dosen memberikan latihan membuat kalimat yang dikerjakan secara kelompok.

Pada bagian Penutup dosen bersama mahasiswa menyimpulkan materi 1 . Terakhir dosen menugaskan setiap individu untuk latihan menyusun kaliamt di rumah. Latihan ini diambil dari buku teks.

\section{Pertemuan ke-3}

Pada pendahuluan, dosen melakukan kegiatan mengumpulkan tugas rumah, kemudian mengambil tiga contoh tugas untuk dikomentari. Selanjutnya dosen menanyakan kembali konsep-konsep materi I. Dosen mengulang kesimpulan materi I secara ringkas. Dosen memberi kesempatan kepada mahasiswa untuk menanyakan halhal yang belum mengerti. Dosen memberikan teks baru yang ada hubungannya dengan topik atau materi 2 .

Pada kegiatan inti, kembali mahasiswa dikelompokkan menjadi 5 kelompok. Dosen membacakan teks yang berhubungan dengan materi 2. Dosen menjelaskan kaidah-kaidah yang berhubungan dengan materi. Setiap kelompoknya diminta untuk mendiskusikan teks tersebut dengan mengidentifikasi bentuk-bentuk kalimat yang sesuai dengan topik. Setiap kelompok menyimpulkan hasil diskusi. Wakil setiap kelompok maju bergantian menjelaskan hasil diskusi.
Mahasiswa lain menanggapi hasil diskusi tersebut secara bergantian. Dosen menanggapi dan membetulkan kesimpulankesimpulan yang keliru. Dosen memberikan latihan membuat kalimat yang dikerjakan secara kelompok, lansung dikoreksi secara bersama.

Pada bagian Penutup dosen bersama mahasiswa menyimpulkan materi 2 . Kemudian dosen menugaskan setiap individu untuk mengerjakan latihan membuat kalimat. Dosen juga menugaskan secara kelompok membuat karangan pendek.

\section{Pertemuan ke-4}

Pelajaran dimulai dengan Pendahuluan. Dosen mengomentari kesalahan-kesalahan mahasiswa dalam tugas sebelumnya. Dosen mengulang materi yang sudah dipelajari pada materi 2 secara ringkas. Dosen menyimpulkan kembali materi 2. Dosen memberi kesempatan kepada mahasiswa untuk bertanya yang belum dipahami. Dosen memberikan teks yang ada hubungannya dengan topik atau materi.

Pada bagian Inti, mahasiswa seperti biasa, dikelompokkan kembali. Dosen membacakan teks yang berhubungan dengan materi. Dosen menjelaskan kaidah-kaidah yang berhubungan dengan materi. Setiap kelompok diminta untuk mendiskusikan teks tersebut dengan mengidentifikasi bentukbentuk kalimat yang sesuai dengan topik. Setiap kelompok menyimpulkan hasil diskusi. Wakil setiap kelompok maju bergantian menjelaskan hasil diskusi. Mahasiswa lain menanggapi hasil diskusi tersebut secara bergantian. Dosen menanggapi dan membetul-kan kesimpulankesimpulan yang keliru. Dosen memberikan latihan membuat kalimat yang dikerjakan secara kelompok, dan hasilnya didiskusikan secara bersama.

Pada bagian penutup, dosen bersama mahasiswa menyimpulkan materi 3 . Dosen menugaskan setiap individu untuk mengerjakan latihan menyusun kalimat yang diambil dari buku bahan ajar di rumah. 


\section{Pertemuan ke-5}

Pada bagian pendahuluan dosen mengomentari tugas yang lalu. Dosen bertanya kepada setiap individu tentang materi 3. Dosen memberi kesempatan mahasiswa untuk bertanya. Dosen mengajak mahasiswa menyimpulkan kembali materi 3. Dosen memberikan teks baru yang berhubungan dengan materi 4 .

Pada bagian Inti mahasiswa dikelompokkan menjadi 5 kelompok. Dosen membacakan sebuah teks materi 4. Dosen menjelaskan kaidah-kaidah yang berhubungan dengan materi. Setiap kelompok diminta untuk mendiskusikan teks tersebut dengan mengidentifikasi bentukbentuk kalimat yang sesuai dengan topik. Setiap kelompok menyimpulkan hasil diskusi. Wakil setiap kelompok maju bergantian menjelaskan hasil diskusi. Mahasiswa lain menanggapi hasil diskusi tersebut secara bergantian. Dosen menanggapi dan membetulkan kesimpulan-kesimpulan yang keliru. Dosen memberikan latihan membuat kalimat yang dikerjakan secara kelompok, hasilnya didiskusikan kembali.

Pada bagian Penutup dosen bersama mahasiswa menyimpulkan materi 4 . Dosen menugaskan setiap individu untuk latihan di rumah.

\section{Pertemuan ke-6}

Pada bagian Pendahuluan Dosen mengomentari tugas lalu dan membetulkan kalimat yang salah. Dosen bertanya kepada setiap individu tentang materi 4. Dosen bersama mahasiswa menyimpulkan kembali materi 4 dengan ringkas. Dosen memberi kesempatan untuk bertanya. Dosen memberi-kan teks baru yang ada hubungannya dengan topik atau materi 5 .

Pada bagian Inti Mahasiswa diarahkan untuk berkelompok kembali. Dosen membacakan teks yang berhubungan dengan materi 5. Dosen menjelaskan kaidahkaidah yang berhubungan dengan materi. Setiap kelompok diminta untuk mendiskusikan teks tersebut dengan mengidentifikasi bentuk-bentuk kalimat yang sesuai dengan topik. Setiap kelompok menyimpulkan hasil diskusi. Wakil setiap kelompok maju bergantian menjelaskan hasil diskusi. Mahasiswa lain menanggapi hasil diskusi tersebut secara bergantian. Dosen menanggapi dan membetulkan kesimpulan-kesimpulan yang keliru. Dosen memberikan latihan membuat kalimat yang dikerjakan secara kelompok.

Pada bagian Penutup Dosen bersama mahasiswa menyimpulkan materi 5. Dosen menugaskan setiap individu untuk latihan di rumah.

\section{Pertemuan ke-7}

Pada bagian Pendahuluan Dosen menjelaskan kesalahan mahasiswa dalam menyusun kalimat. Dosen mengajukan beberapa pertanyaan tentang materi 5 kepada beberapa orang mahasiswa. Dosen mengajak mahasiswa untuk menyimpulkan kembali materi 5 secara ringkas. Dosen memberi kesempatan bertanya kepada mahasiswa. Dosen memberikan teks yang ada hubungannya dengan topik/materi 6 .

Pada bagian inti mahasiswa dikelompokkan. Dosen membacakan teks yang berhubungan dengan materi. Dosen menjelaskan kaidah-kaidah yang berhubungan dengan materi. Setiap kelompok diminta mendiskusikan teks tersebut dengan meng-identifikasi bentukbentuk kalimat yang sesuai dengan topik. Setiap kelompok menyimpulkan hasil diskusi. Wakil setiap kelompok maju bergantian menjelaskan hasil diskusi. Mahasiswa lain menanggapi hasil diskusi tersebut secara bergantian. Dosen menanggapi dan membetulkan kesimpulankesimpulan yang keliru. Dosen memberikan latihan membuat kalimat yang dikerjakan secara kelompok.

Pada bagian Penutup Dosen bersama mahasiswa menyimpulkan materi 6. Dosen menugaskan setiap individu untuk latihan menyusun kalimat di rumah.

\section{Pertemuan ke-8}

Pada bagian Pendahuluan dosen mendiskusikan kesalahan mahasiswa dalam 
menyusun kalimat. Dosen menanyakan kembali konsep materi 6. Dosen mengajak mahasiswa menyimpulkan kembali materi 6 . Dosen memberi peluang mahasiswa untuk menanyakan konsep yang kurang dipahami. Dosen memberikan teks yang ada hubungannya dengan topik /materi 7 .

Pada bagian Inti mahasiswa dikelompokkan kembali. Dosen membacakan sebuah teks yang berhubungan dengan materi 7. Dosen menjelaskan kaidahkaidah yang berhubungan dengan materi. Setiap kelompok diminta untuk mendiskusikan teks tersebut dengan mengidentifikasi bentuk-bentuk kalimat yang sesuai dengan topik. Setiap kelompok menyimpulkan hasil diskusi. Wakil setiap kelompok maju bergantian menjelaskan hasil diskusi. Mahasiswa lain menanggapi hasil diskusi tersebut secara bergantian. Dosen menanggapi dan membetulkan kesimpulan-kesimpulan yang keliru. Dosen memberikan latihan membuat karangan pendek yang dikerjakan secara kelompok.

Pada bagian Penutup Dosen bersama mahasiswa menyimpulkan materi 7 . Dosen menugaskan setiap individu membuat karangan pendek dengan topik yang ditentukan dosen dengan menggunakan bentuk-bentuk kalimat yang sudah dipelajari.

\section{Pertemuan ke-9}

Pertemuan ke sembilan adalah tes akhir siklus I. Pada hari ini mahasiswa juga mengumpulkan tugas mengarang pendek akhir siklus I.

\section{Refleksi}

Refleksi diarahkan kepada dua komponen yaitu refleksi terhadap pelaksanaan proses belajar mengajar yang dilaksanakan dosen dan refleksi terhadap sikap mahasiswa dalam proses pembelajaran.

Pada siklus pertama teridentifikasi beberapa catatan yang dapat diamati. Pada dua pertemuan awal dosen memberikan kebebasan pada kelompok mahasiswa dalam diskusi dan tidak memfasilitasi kegiatan diskusi. Hal ini dilakukan mungkin agar kelompok dapat secara mandiri membentuk pola diskusi yang diinginkan. Mungkin tujuan awalnya untuk meningkatkan kemandirian. Namun pada pertemuan berikutnya dosen berusaha mem-fasilitasi dan membantu kelompok dalam kegiatan diskusi.

Dalam hal menjawab pertanyaan dari mahasiswa peserta diskusi, dosen cenderung monoton tanpa variasi. Namun pada akhirakhir siklus pertama dosen mulai menjawab pertanyaan-pertanyaan secara variatif sehingga pelaksanaan pembelajaran mulai lebih hidup. Pada siklus pertama ini juga dosen kurang memperhatikan motivasi dan bebera-pa kali tidak ada evaluasi setiap akhir pelajaran.

Sikap mahasiswa dalam siklus pertama ini berfariasi. Pada awal perkuliahan teramati bahwa mahasiswa kurang serius, kurang mau berdiskusi dan tidak mampu menghubungkan pelajaran baru dengan pelajaran sebelumnya. Khususnya dalam hal berdiskusi materi yang sulit mahasiswa cenderung apatis. Namun pada akhir-akhir siklus hal-hal yang negatif seperti itu mulai hilang. Namun perlu dicatat bahwa mereka pada dasarnya bersemangat dalam berdiskusi serta memperlihatkan ketertarikan terhadap materi Nahu II ini. Ini artinya mereka bersikap positif dalam pembelajaran berbasis kelompok.

\section{B. Pelaksanaan Siklus II}

1) Perencanaan

Pertemuan ke-10: $\quad$ Penyajian materi 8: (العدد وتمييزه).

Materi ini meliputi penggunaan bilangan dalam kalimat bahasa Arab. yang terdiri dari:( عدد مفرد), ( عدد مركب ), (لفظ العقد ), dan (عدد معطوف ( عند ).

Pertemuan 11:Penyajian materi 9: نائب) (الفاعل )

Materi meliputi bentuk kalimat pasif.

Pertemuan 12:Penyajian materi 10: ظرفان)

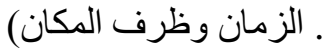


Materi ini meliputi penggunaan berbagai macam keterangan tempat dan keterangan waktu.

Pertemuan 13:Penyajian materi 11: (الحال) . Materi ini meliputi bentuk keterangan keadaan.

Pertemuan 14:Penyajian materi 12: أنواع)

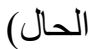

Materi ini meliputi macam-macam bentuk keterangan keadaan.

Pertemuan 15:Penyajian materi 13: المستثنى) (بالا وغير وسوى)

Materi ini meliputi keterangan penge-cualian.

Pertemuan 16: Tes akhir siklus II: الاختبار) (الثاني)

\section{2) Tindakan}

Tindakan pada siklus II terdiri dari 7 kali pertemuan, 6 kali tindakan penyajian materi dan satu kali tes akhir siklus II. Pelaksanaan tindakan pada siklus ini adalah penyempurnaan dari pelaksanaan siklus I. Kekurangan-kekurangan yang terdapat pada siklus I diperbaiki. Mahasiswa tetap belajar dan berlatih secara berkelompok. Kelompok mahasiswa tetap terdiri dari 5 kelompok. Kelompok 1 dan 2 terdi dari 4 orang. Kelompok 3, 4, dan 5 terdiri dari 5 orang mahasiswa. Anggota kelompok masih sama dengan anggota kelompok siklus I. Pelaksanaan penyajian materi masih sama seperti penyajian pada siklus I.

Tindakan Pertemuan 10: Penyajian materi 8

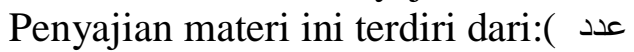
دفرد), ( عدد مركب ), (لفظ العقود), dan (عدد معطوف ) ). Bilangan ini meliputi bilangan 1-10, 11-99, dan bilangan 100, 1000 dan seterusnya. Penyajian materi ini sudah sesuai dengan rencana pelajaran yang sudah disusun.

Tindakan Pertemuan 11: Penyajian materi 9 Penyajian materi adalah pembentukan kalimat pasif, serta pembentukan kata kerja pasif. Penyajian sudah sesuai dengan rencana pelajaran yang sudah disusun.

\section{Tindakan Pertemuan 12: Penyajian materi} 10

Penyajian materi 10 mengenai pengembangan kalimat sederhana dengan menggunakan bermacam-macam bentuk keterangan tempat dan keterangan waktu. Penyajian materi ini sudah sesuai dengan rencana pelajaran yang sudah disusun.

\section{Tindakan Pertemuan 13: Penyajian materi} 11

Penyajian materi 11 dilaksanakan pada hari Kamis 8 November 2007. Materi pada pertemuan 13 ini meliputi keterangan keadaan dengan segala aturannya. Penyajian materi ini sudah sesuai dengan rencana pelajaran yang sudah disusun (terlampir).

\section{Tindakan Pertemuan 14: Penyajian materi} 12

Penyajian materi 12 dilaksanakan pada hari Selasa13 November 2007. Materi 12 ini adalah lanjutan dari materi 11, yaitu macam-macam keterangan keadaan. Penyajian materi ini sudah sesuai dengan rencana pelajaran yang sudah disusun.

Tindakan Pertemuan 15: Penyajian materi 13

Penyajian materi 13 dilaksanakan pada hari Kamis 15 November 2007. Materi 13 meliputi pengembangan kalimat sederhana dengan menggunakan pengecualian, baik pakai Illa (إل) ) atau ghair dan siwaa (غير وسوى). Penyajian materi ini sudah sesuai dengan rencana pelajaran yang sudah disusun. Pada pertemuan terakhir ini mahasiswa juga ditu-gaskan membuat karangan bebas yang harus dikumpulkan pada hari tes siklus II. Mahasiswa harus menggunakan bentuk-bentuk kalimat yang sudah dipelajari.

Tindakan Pertemuan 16: Tes akhir siklus II Tes akhir siklus dua dilaksanakan pada hari Selasa 20 November 2007. Tes 
berbentuk pilihan berganda sebanyak 50 soal.

\section{Pengamatan}

\section{Pertemuan kesepuluh}

Pada awal siklus kedua (pertemuan kesepuluh) dosen memulai kegiatan pembelajaran materi 8 (delapan) dengan pendahuluan. Kegiatan yang dilakukan dosen sebagai berikut. Pertama, dosen menjelaskan kesalahan yang dilakukan mahasiswa dalam tugas rumah, mengajak mahasiswa meng-ungkapkan kembali konsep-konsep materi yang lalu, meminta mahasiswa menyimpulkan kembali materi 7 dan menghubungkannya dengan materi baru, memberikan kesempatan bertanya kepada, dan kemudian memperlihat-kan teks yang berhubungan dengan materi baru.

Kegiatan inti pembelajaran dimulai dengan mengelompokkan mahasiswa seperti biasanya. Selanjutnya dosen membacakan teks yang berhubungan dengan materi 8 . Menjelaskan kaidah-kaidah yang berhubungan dengan materi. Kemudian setiap kelompok diminta untuk mendiskusikan teks tersebut dengan mengidentifikasi bentuk-bentuk kalimat yang sesuai dengan topik. Setiap kelompok menyimpulkan hasil diskusi. Wakil setiap kelompok maju bergantian menjelaskan hasil diskusi. Mahasiswa lain menanggapi hasil diskusi tersebut secara bergantian. Dosen menanggapi dan membetulkan kesimpulan yang keliru. Akhir dari kegiatan inti, dosen memberikan latihan membuat kalimat yang dikerjakan secara kelompok.

Pada bagian Penutup dosen bersama mahasiswa menyimpulkan materi 8 . Selanjutnya dosen menugaskan setiap individu untuk latihan menyusun kalimat di rumah.

\section{Pertemuan kesebelas}

Seperti biasa dosen memulai kegiatan pembelajaran dengan pendahuluan. Kegiatan yang dilakukan dosen sebagai berikut: pertama dosen menjelaskan kesalahan yang dilakukan mahasiswa dalam tugas rumah, mengajak mahasiswa mengungkapkan kembali konsep-konsep materi yang lalu, meminta mahasiswa menyimpulkan kembali materi 8 dan menghubungkannya dengan materi baru, memberikan kesempatan bertanya kepada mahasiswa, dan kemudian memperlihatkan teks yang berhubungan dengan materi baru.

Kegiatan inti pembelajaran dimulai dengan mengelompokkan mahasiswa seperti biasanya. Selanjutnya dosen membacakan teks yang berhubungan dengan materi 9 . Menjelaskan kaidah-kaidah yang berhubungan dengan materi. Kemudian setiap kelompok diminta untuk mendiskusikan teks tersebut dengan mengidentifikasi bentuk-bentuk kalimat yang sesuai dengan topik. Setiap kelompok menyimpulkan hasil diskusi.

Wakil setiap kelompok maju bergantian menjelaskan hasil diskusi. Mahasiswa lain menanggapi hasil diskusi tersebut secara bergantian. Dosen menanggapi dan membetulkan kesimpulan yang keliru. Akhir dari kegiatan inti, dosen memberikan latihan membuat kalimat yang dikerjakan secara kelompok.

Pada bagian Penutup dosen bersama mahasiswa menyimpulkan materi 9. Selanjutnya dosen menugaskan setiap individu untuk latihan menyusun kalimat di rumah.

\section{Pertemuan kedua belas}

Dosen memulai kegiatan pembelajaran dengan pendahuluan. Kegiatan yang dilakukan dosen sebagai berikut. Pertama, dosen menjelaskan kesalahan yang dilakukan mahasiswa dalam tugas rumah, mengajak mahasiswa mengungkapkan kembali konsep-konsep materi yang lalu, meminta mahasiswa menyimpulkan kembali materi 9 dan menghubungkannya dengan materi baru, memberikan kesempatan bertanya kepada ma-hasiswa, dan kemudian memperlihatkan teks yang berhubungan dengan materi baru.

Kegiatan inti pembelajaran dimulai dengan mengelompokkan mahasiswa seperti 
biasanya. Selanjutnya dosen membacakan teks yang berhubungan dengan materi 10 . Menjelaskan kaidah-kaidah yang berhubungan dengan materi. Kemudian setiap kelompok diminta untuk mendiskusikan teks tersebut dengan mengidentifikasi bentuk-bentuk kalimat yang sesuai dengan topik. Setiap kelompok menyimpulkan hasil diskusi. Wakil setiap kelompok maju bergantian menjelaskan hasil diskusi. Mahasiswa lain menanggapi hasil diskusi tersebut secara bergantian. Dosen menanggapi dan membetulkan kesimpulan yang keliru. Akhir dari kegiatan inti, dosen memberikan latihan membuat kalimat yang dikerjakan secara kelompok.

Pada bagian Penutup dosen bersama mahasiswa menyimpulkan materi 10 . Selanjutnya dosen menugaskan setiap individu untuk latihan menyusun kalimat di rumah.

\section{Pertemuan ketiga belas}

Pertama-tama dosen menjelaskan kesalahan yang dilakukan mahasiswa dalam tugas rumah, mengajak mahasiswa mengungkapkan kembali konsep-konsep materi yang lalu, meminta mahasiswa menyimpulkan kembali materi 10 dan menghubungkannya dengan materi baru, memberikan kesempatan bertanya kepada mahasiswa, dan kemudian memperlihatkan teks yang berhubungan dengan materi baru.

Kegiatan inti pembelajaran dimulai dengan mengelompokkan mahasiswa seperti biasanya. Selanjutnya dosen membacakan teks yang berhubungan dengan materi 11 . Menjelaskan kaidah-kaidah yang berhubungan dengan materi. Kemudian setiap kelompok diminta untuk mendiskusikan teks tersebut dengan mengidentifikasi bentuk-bentuk kalimat yang sesuai dengan topik. Setiap kelompok menyimpulkan hasil diskusi.

Wakil setiap kelompok maju bergantian menjelaskan hasil diskusi. Mahasiswa lain menanggapi hasil diskusi tersebut secara bergantian. Dosen menanggapi dan membetulkan kesimpulan yang keliru. Akhir dari kegiatan inti, dosen memberikan latihan membuat kalimat yang dikerjakan secara kelompok

Pada bagian Penutup dosen bersama mahasiswa menyimpulkan materi 11 . Selanjutnya dosen menugaskan setiap individu untuk latihan menyusun kalimat di rumah.

\section{Pertemuan keempat belas}

Kegiatan pendahuluan yang dilakukan dosen pertama-tama adalah menjelaskan kesalahan yang dilakukan mahasiswa dalam tugas rumah, mengajak mahasiswa mengungkapkan kembali konsep-konsep materi yang lalu, meminta mhs menyimpulkan kembali materi 11 dan menghubungkannya dengan materi baru, memberikan kesempatan bertanya kepada mahasiswa, dan kemudian memperlihatkan teks yang berhubungan dengan materi baru.

Kegiatan inti pembelajaran dimulai dengan mengelompokkan mahasiswa seperti biasanya. Selanjutnya dosen membacakan teks yang berhubungan dengan materi 12 . Menjelaskan kaidah-kaidah yang berhubungan dengan materi. Kemudian setiap kelompok diminta untuk mendiskusikan teks tersebut dengan mengidentifikasi bentuk-bentuk kalimat yang sesuai dengan topik. Setiap kelompok menyimpulkan hasil diskusi. Wakil setiap kelompok maju bergantian menjelaskan hasil diskusi. Mahasiswa lain menanggapi hasil diskusi tersebut secara bergantian. Dosen menanggapi dan membetulkan kesimpulan yang keliru. Akhir dari kegiatan inti, dosen memberikan latihan membuat kalimat yang dikerjakan secara kelompok.

Pada bagian Penutup dosen bersama mahasiswa menyimpulkan materi 12 . Selanjutnya dosen menugaskan setiap individu untuk latihan menyusun kalimat di rumah.

\section{Pertemuan kelima belas}

Pertama-tama dosen menjelaskan kesalahan yang dilakukan mahasiswa dalam tugas rumah, mengajak mahasiswa mengungkapkan kembali konsep-konsep materi yang lalu, meminta mahasiswa 
menyimpulkan kembali materi 12 dan menghubungkannya dengan materi baru, memberikan kesempatan bertanya kepada mahasiswa, dan kemudian memperlihatkan teks yang berhubungan dengan materi baru.

Kegiatan inti pembelajaran dimulai dengan mengelompokkan mahasiswa seperti biasanya. Selanjutnya dosen membacakan teks yang berhubungan dengan materi 13 . Menjelaskan kaidah-kaidah yang berhubungan dengan materi. Kemudian setiap kelompok diminta untuk mendiskusikan teks tersebut dengan mengidentifikasi bentuk-bentuk kalimat yang sesuai dengan topik. Setiap kelompok menyimpulkan hasil diskusi. Wakil setiap kelompok maju bergantian menjelaskan hasil diskusi. Mahasiswa lain menanggapi hasil diskusi tersebut secara bergantian. Dosen menanggapi dan membetulkan kesimpulan yang keliru. Akhir dari kegiatan inti, dosen memberikan latihan membuat kalimat yang dikerjakan secara kelompok

Pada bagian Penutup dosen bersama mahasiswa menyimpulkan materi 13 . Selanjutnya dosen menugaskan setiap individu untuk latihan menyusun kalimat di rumah.

\section{Pertemuan ke enam belas}

Pertemuan keenam belas adalah tes akhir siklus II. Pada hari ini mahasiswa juga mengumpulkan tugas mengarang pendek akhir siklus II.

\section{3) Refleksi}

Sama seperti pada siklus satu, refleksi diarahkan kepada dua komponen yaitu refleksi terhadap pelaksanaan proses belajar mengajar yang dilaksanakan dosen dan refleksi terhadap sikap mahasiswa dalam proses pembelajaran.

Pada siklus kedua ini teramati bahwa dosen sudah menjawab setiap pertanyaan yang diajukan mahasiswa dengan berbagai cara, memfasilitasi kegiatan diskusi mahasiswa, memotivasi mahasiswa dalam berdiskusi, melaksanakan kegiatan belajar mengajar sesuai dengan satuan acara perkuliahan, dan melakukan evaluasi setiap selesai KBM. Terlaksananya semua indikator dalam pelak-sanaan pembelajaran tentu berakibat terhadap keberhasilan pembelajaran berbasis kelompok.

Sikap mahasiswa dalam siklus kedua ini lebih terarah. Walaupun dalam beberapa hal mahasiswa melaksanakan diskusi kurang tertib dan kurang mampu menghubungkan materi baru dengan materi sebelumnya, namun dalam banyak hal mereka memperlihatkan sikap positif. Mahasiswa bersemangat, lebih serius dalam diskusi, senang belajar dengan berdiskusi, memiliki keinginan yang kuat untuk bertanya kepada dosen tentang materi pelajaran yang disajikan, mau berdiskusi tentang materi yang kurang dipahami, tertarik dengan cara belajar berkelompok, memiliki sikap positif terhadap cara belajar berkelompok, berdiskusi dengan tertib, sangat akrab dalam berdiskusi, saling menghargai dalam mengemukakan pendapat, dan mereka sangat termotivasi untuk belajar materi Nahu II ini. Ini artinya mereka bersikap positif dalam pembelajaran berbasis kelompok.

\section{Analisis Reflektif}

Tanggapan mahasiswa terhadap pelaksanaan PBK dalam pengajaran Nahu II dipaparkan di sini sebagai bagian dari analisis reflektif dan pembahasan evaluatif. Dalam hal belajar dengan cara belajar kelompok dalam pelajaran Nahu II hanya satu orang mahasiswa yang merasakan tidak senang, sedangkan sisanya sejumlah 22 orang menyatakan senang. Namun bila ditanya tentang keserius-an belajar dengan cara berkelompok ternyata terdapat enam orang yang merasa tidak serius. Dalam hal kebebasan mengemukakan pendapat, semua mahasiswa menyetujuinya dan bahkan merasa lebih akrab, hanya satu orang yang berbeda pendapat.

Dengan adanya belajar secara berkelompok ini mahasiswa merasa lebih berani bertanya kepada temannya tentang materi pelajaran yang kurang dipahami. Penghar-gaan terhadap pendapat orang lain 
disetujui 100\% mahasiswa. Di samping itu mereka merasa lebih mudah belajar secara berkelompok sehingga merekapun termotivasi belajar Nahu II.

Di lain pihak dosen selalu menjawab pertanyaan yang diajukan mahasiswa dan menghargai pendapat mahasiswa. Namun demikian dosen tidak sepenuhnya memfasilitasi setiap kegiatan selama belajar kelompok. Tapi mahasiswa mengakui bahwa dosen berperan memberikan motivasi bagi mahasiswa.

Tabel 1. Perbandingan Nilai Kerja Kelompok Siklus I dengan Siklus II

\begin{tabular}{|l|c|c|c|c|}
\hline \multirow{2}{*}{ Aspek yang Dinilai } & \multicolumn{2}{|c|}{ Siklus Pertama } & \multicolumn{2}{c|}{ Siklus Kedua } \\
\cline { 2 - 5 } & Nilai Total & Rata-Rata & NilaiTotal & Rata-Rata \\
\hline Kerjasama & 340 & 14,78 & 430 & 18,70 \\
\hline Keaktifan & 360 & 15,65 & 425 & 18,48 \\
\hline Keberanian & 365 & 15,87 & 445 & 19,35 \\
\hline Menghargai Pendapat & 390 & 16,96 & 470 & 20,43 \\
\hline Total & 1455 & 63,26 & 1770 & 76,96 \\
\hline
\end{tabular}

Dalam tabel di atas terlihat adanya peningkatan pada semua aspek kerja kelompok yang dinilai. Nilai kerja sama meningkat dari rata-rata 14,78 menjadi 18,70 , keaktifan meningkat dari rata-rata 15,65 menjadi 18,48, keberanian meningkat dari rata-rata 15,87 menjadi 19,35, sedangkan penghargaan terhadap pendapat orang lain meningkat dari 16,96 menjadi 20,43. Jadi secara keseluruhan terjadi peningkatan dari rata-rata 63,26 menjadi $76,96$.

Pada Lampiran XII terlihat perbandingan hasil tes mahasiswa pada siklus I dibandingkan dengan nilai tes pada siklus II. Pada siklus I rentangan nilai hasil tes mahasiswa antara 33 nilai terendah dan 77 nilai tertinggi. Rata-rata nilai hasil tes siklus I adalah 56,30. Sementara itu, nilai hasil tes terendah pada siklus II adalah 40 dan nilai tertinggi 98 , sedangkan rata-rata nilai tes siklus II adalah 67,61. Bila dibandingkan nilai tes siklus pertama dan kedua terjadi peningkatan $20 \%$.

Peningkatan juga terjadi pada tugas mengarang mahasiswa pada siklus II dibandingkan dengan siklus I. Nilai terendah tugas mengarang pada siklus I adalah 40 sedangkan nilai tertinggi adalah 71 . Nilai tugas mengarang pada siklus II terjadi peningkatan yaitu nilai terendah 60 dan nilai tertinggi 96. Rata-rata nilai tugas mengarang pada siklus I ini adalah 52,87. Sementara itu rata-rata nilai pada siklus II adalah 73 . Bila dibandingkan dengan nilai yang diperoleh pada siklus I terjadi peningkatan yaitu $38 \%$.

\section{1) Pembahasan Evaluatif}

Berdasarkan beberapa analisis reflektif pada siklus pertama, siklus kedua dan analisis secara keseluruhan dapat ditemukan beberapa hal sebagai bahan pembahasan. Pembelajaran bahasa berbasis kelompok memiliki berbagai karakteristik yang dapat meningkatkan aktifitas dan perilaku positif mahasiswa dalam belajar.

Aktifitas dan perilaku positif diartikan sebagai terjadinya interaksi dan suasana belajar yang kondusif. Dalam berbagai pengamatan selama proses penelitian berlangsung, baik yang dilakukan oleh peneliti maupun oleh kolaborator serta pendapat mahasiswa terungkap beberapa temuan yang mendukung konsep tersebut.

Beberapa perkembangan seperti peningkatan kemampuan menyusun kalimat sederhana dalam menyusun karangan dapat diamati dari tugas menulis karangan dalam bahasa Arab sederhana pada akhir siklus pertama dan siklus kedua. Pembelajaran berbasis kerja sama adalah sebuah pendekatan pengajaran yang memanfaatkan kegiatan kooperatif secara maksimum dengan melibatkan pasangan-pasangan dan kelompok kecil pembelajar di kelas. Pembelajaran Berbasis Kerja sama adalah 
kegiatan belajar kelompok yang diatur sedemikian rupa hingga pembelajaran bergantung pada pertukaran informasi yang terstruktur secara sosial di antara pembelajar dalam kelompok. Dalam kelompok tersebut setiap pembelajar bertanggung jawab atas pembelajaran mereka masing-masing dan termotivasi untuk memperluas pengetahuan mereka khususnya pengetahuan menyusun kalimat sederhana bahasa Arab.

Karakteristik kooperatif dalam pembelajaran bahasa berbasis kelompok berpengaruh positif pada peningkatan kerja sama dalam memahami materi pelajaran Nahu, khususnya pemahaman struktur kalimat sederhana. Hal ini dapat terjadi karena faktor adanya interaksi positif dalam belajar kelompok. Mahasiswa memiliki berbagai sumber dalam memecahkan persoalan belajar yang dialami selama proses pembelajaran berlangsung. Sesama mahasiswa saling bertanya dan saling membantu dalam memecahkan persoalan belajar bahasa Arab. Keakraban di antara mereka tercipta dan terjalin lebih baik dalam suasana akademik yang sangat kondusif.

Mahasiswa bebas mengemukakan pendapat dan menghargai perbedaan pendapat yang terjadi selama diskusi berlangsung. Walaupun bebas namun tetap tertib dan serius. Hal ini menjadi faktor pendukung dalam memudahkan mahasiswa belajar. Suasana kondusif seperti itu jarang dapat ditemukan pada sistem pembelajaran dengan pendekatan konvensional lainnya. Hal ini terlihat nyata per-bedaan yang terjadi antara pengajaran Nahu I dengan pendekatan konvensional, dengan pengajaran Nahu II dengan pendekatan kooperatif. Kedua mata kuliah ini diajarkan oleh peneliti sendiri pada semester yang berurutan.

Faktor dosen sebagai fasilitator sangat berperan menciptakan suasana kondusif sehingga memperlancar dan mempermudah pemahaman materi pembelajaran. Selain sebagai fasilitator dosen juga berfungsi motivator yang dapat menggerakkan keaktifan, kesenangan, keseriusan, dan keberanian bertanya mahasiswa selama pembelajaran.

Berdasarkan kenyataan di atas, pembelajaran bahasa berbasis kelompok ini dapat meningkatkan prestasi seluruh mahasiswa, termasuk mereka yang berbakat atau secara akademik mendapat banyak kendala, membantu guru membangun hubungan positif di antara mahasiswa, dan memberikan pengalaman berharga bagi mahasiswa berupa peningkatan hubungan sosial, psikologis, dan kognitif.

\section{PENUTUP} Simpulan

Pembelajaran berbasis kelompok adalah sebuah pendekatan pengajaran yang memanfaatkan kegiatan kooperatif secara maksimum dengan melibatkan pasanganpasangan dan kelompok kecil pembelajar di kelas, sehingga dengan demikian pembelajaran bahasa berbasis kelompok dapat meningkatkan prestasi belajar Nahu II dalam belajar kalimat sederhana bahasa Arab. Data hasil belajar menyusun kalimat sederhana dalam karangan berbahasa Arab yang ditugaskan kepada mahasiswa menunjukkan adanya peningkatan kemampuan secara kuantitatif dilihat dari persentase peningkatan.

Pembelajaran bahasa berbasis kelompok dapat meningkatkan kerja sama dalam belajar, kegairahan belajar, kesengan belajar, keseriusan, keakraban, keberanian, dan motivasi belajar mahasiswa. Data ini terekam dari pengamatan selama proses pembelajaran berlangsung dan angket yang diisi oleh mahasiswa.

Terciptanya suasana belajar yang menyenangkan, terjalinnya hubungan kerja sama yang lebih baik dan akrab, adanya keterbukaan, dan terjadi peningkatan motovasi belajar berpengaruh positif dalam mencipta-kan situasi dan kondisi belajar yang kondusif.

\section{A. Saran}

Pembelajaran bahasa berbasis kelompok perlu dianjurkan sebagai salah 
satu strategi pembelajaran bahasa Arab dalam meningkatkan keaktifan dan kerja sama mahasiswa dalam belajar. Agar efektifitasnya meningkat, maka penelitian secara terus menerus juga perlu dilakukan selain dapat mengembangkan pengetahuan dalam metodologi pengajaran bahasa Arab juga dapat meningkatkan kemampuan meneliti terutama bagi dosen yang mengajarkan bahasa Arab.

\section{DAFTAR PUSTAKA}

Aqib, Z. (2006). Penelitian Tindakan Kelas. Bandung: Yrama Widya.

Arikunto, S. dkk. (2007). Penelitian Tindakan Kelas. Jakarta: Bumi Aksara.

Kagan, S., \& Olsen. (1992). Cooperative Learning. Gaan Juan Copistano. KCL.

McGroarty, M. (1989). The Benefits of Coperative Learning Arrangement in Second Language Instructiion. $N A B E$ Journal, 127-143.

Olsen, R. E. W. B., \& Kagan, S. (1992). About Cooperative Learning in Coelho Kessler, p: 2-25. New York: Precentic Hall

Richards, J. C., \& Theodore S. Rodengan ers. (2005). Approachs and Methods in Language Teaching. New York: Cambride University Press.

Shiniy, M. I, dkk. (1982). Al Qawaidul 'Arabiyyah Al Muyassarah, jilid 1. Riyadh: Universitas Malik Suud.

Wallace, M. J. (1991). Training Foreign Language Terchers. A Reflective Approach. Cambride e: Cambride University Pres 